\title{
KEEFEKTIFAN MODEL PEMBELAJARAN PAIR CHECK DAN NUMBERED-HEADS TOGETHER (NHT) DITINJAU DARI HASIL BELAJAR DALAM PEMBELAJARAN IPS KELAS 4 SDN GUGUS MAHESA JENAR AMBARAWA
}

\author{
Galuh Adi Prakoso \\ Pendidikan Guru Sekolah Dasar - FKIP - UKSW Salatiga
}

\begin{abstract}
ABSTRAK
Pembelajaran IPS adalah pembelajaran bersifat hafalan dan hubungan interaksi masyarakat dalam kehidupan sehari-hari. Model pembelajaran Pair Check dan Numbered-Heads Together (NHT) adalah model pembelajaran yang tepat menjadi solusi permasalahan pembelajaran IPS. Tujuan penelitian ini adalah untuk mengetahui adanya perbedaan hasil belajar IPS yang signifikan dalam pembelajaran menggunakan model Pair Check dan model Numbered-Heads Together (NHT) pada siswa kelas IV SDN gugus Mahesa Jenar Ambarawa. Penelitian eksperimen jenis quasi experiment dengan design Nonequivalent Control Group Design. Teknik analisis data menggunakan tes dan observasi. Populasi penelitian adalah gugus Mahesa Jenar Ambarawa dan sampelnya siswa kelas IV SDN Sudirman, SDN Lodoyong 02 dan SDN Tambakboyo 01. Teknik analisis data untuk menguji skor hasil belajar siswa adalah uji t dengan teknik Independent Sample T Test. Hasil post test siswa pada kelompok eksperimen dan kelompok kontrol setelah dilakukan uji t (uji beda rata-rata) menunjukkan signifikansi 0,001 karena signifikan $<0,05$ maka ada pengaruh yang signifikan model pembelajaran Pair Check dan NumberedHeads Together (NHT) terhadap hasil belajar IPS pada SDN gugus Mahesa Jenar Ambarawa. Berdasarkan hasil uji beda t maka disarankan guru untuk menggunakan model pembelajaran Numbered-Heads Together (NHT) karena ada perbedaan hasil belajar yang signifikan dalam pembelajaran IPS Kelas IV SDN gugus Mahesa Jenar Ambarawa.
\end{abstract}

Kata kunci: : Pair Check, Numbereds-Heads Together (NHT), Pembelajaran IPS.

\section{PENDAHULUAN}

Pendidikan nasional berfungsi mengembangkan kemampuan dan membentuk watak serta peradapan bangsa yang bermartabat dalam rangka mencerdaskan kehidupan bangsa, bertujuan untuk berkembangnya potensi siswa agar menjadi manusia beriman dan bertakwa kepada Tuhan Yang Maha Esa, berakhlak mulia, sehat, berilmu, cakap, kreatif, mandiri, dan menjadi warga negara yang demokratis serta bertanggung jawab (UU no. 20 tahun 2003 pasal 3). 
Standar Isi Kurikulum Tingkat Satuan Pendidikan dalam Peraturan Menteri Pendidikan Nasional nomor 22 tahun 2006 (BSNP, 2006: 159), mata pelajaran IPS mengkaji seperangkat peristiwa, fakta, konsep, dan generalisasi yang berkaitan dengan isu sosial. Melalui mata pelajaran IPS, siswa diarahkan untuk dapat menjadi warga negara Indonesia yang demokratis, dan bertanggung jawab, serta warga dunia yang cinta damai. Oleh karena itu mata pelajaran IPS dirancang untuk mengembangkan pengetahuan, pemahaman, dan kemampuan analisis terhadap kondisi sosial masyarakat dalam memasuki kehidupan bermasyarakat yang dinamis.

Ilmu Pengetahuan Sosial sebagai suatu program pendidikan yang merupakan suatu keseluruhan yang pada pokoknya mempersoalkan manusia dalam lingkungan alam fisik, maupun dalam lingkungan sosialnya (Buchari Alma dalam Susanto, 2012: 141). Tujuan pendidikan IPS adalah untuk mempersiapkan siswa menjadi warga negara yang baik dalam kehidupannya di masyarakat, mengembangkan kemampuan siswa menggunakan penalaran dalam mengambil keputusan setiap persoalan yang dihadapinya (Gross dalam Solihatin dan Raharjo, 2011: 14).

Pola pembelajaran pendidikan IPS menekankan pada unsur pendidikan dan pembekalan pada siswa. Penekanan pembelajarannya bukan sebatas pada upaya menjejali siswa dengan sejumlah konsep yang bersifat hafalan, melainkan terletak pada upaya agar mereka mampu menjadikan apa yang telah mereka pelajari sebagai bekal dalam memahami dan ikut serta dalam melakoni kehidupan masyarakat. Oleh karena itu, rancangan pembelajaran guru hendaknya dapat memenuhi penilaian yang dilakukan secara komprehensif untuk menilai sikap, pengetahuan serta keterampilan siswa agar pembelajaran yang dilakukan benar-benar bermanfaat dan berguna bagi siswa (Kemendikbud, 2013: 5).

Melihat dari penjabaran diatas proses pembelajaran IPS perlu dilaksanakan dengan multi strategi, multi metode, dan multi media dalam rangka mencapai tujuan pembelajaran IPS. Pembelajaran IPS agar menarik bagi siswa SD, yaitu guru harus merancang dan melaksanakan pembelajaran yang menarik dan menantang, misalnya kegiatan observasi, inkuiri, apresiasi, mengorganisasi, dan menilai hasil kerja sendiri.

Namun fakta di lapangan diperoleh hasil observasi dan evaluasi pembelajaran IPS pada siswa kelas IVA SDN Sudirman semester II tahun pelajaran 2014/2015 siswa yang mencapai KKM (70) baru 24 siswa atau 75\% dari 32 siswa dan kelas IVB SDN Sudirman yang mencapai KKM (70) baru 26 siswa atau $81 \%$. dari 31 siswa. Sedangkan pada siswa kelas IV SDN Lodoyong 02 semester II tahun pelajaran 2014/2015 yang mencapai KKM (64) baru 24 siswa atau 63\% dari total 38 siswa dan pada siswa kelas IV SDN Tambakboyo 01 tahun pelajaran 2014/2015 
Keefektifan Model Pembelajaran Pair Check Dan Numbered-Heads Together (NHT) ditinjau dari Hasil Belajar Dalam Pembelajaran IPS Kelas 4 SDN Gugus Mahesa Jenar Ambarawa (Galuh Adi Prakoso)

yang mencapai KKM (65) baru 30 siswa atau 69\% dari total 43 siswa. Dengan melihat data hasil observasi, wawancara,dan evaluasi tersebut menunjukkaan permasalahan rendahnya pembelajaran IPS. Banyak faktor yang menimbulkan masalah tersebut, menurut siswa mata pelajaran IPS adalah mata pelajaran yang bersifat hafalan dan kebanyakan dari siswa sulit untuk menghafalkan materi IPS yang terlalu banyak. Guru juga banyak menggunakan metode ceramah dalam proses belajar mengajar dan jarang menggunakan alat peraga, akibatnya banyak siswa yang merasa bosan mengikuti proses belajar mengajar. Siswa tanpa diberi kesempatan untuk mencoba, berkolaborasi dengan temannya dan berfikir kritis, mereka lebih memilih untuk bermain sendiri, mengobrol dengan teman, tidur di kelas, atau mengganggu teman yang lain dan proses belajar mengajar menjadi tidak kondusif, tujuan pembelajaran juga tidak tersampaikan.. Untuk mengatasi masalah tersebut, maka harus diberikan suatu metode atau model yang sesuai untuk mata pelajaran IPS.

Berdasarkan pada kenyataan tersebut, maka yang perlu diperhatikan adalah mengubah cara pengajaran yang tadinya monoton berpusat pada guru menjadi berpusat pada siswa sehingga tujuan pembelajaran dapat tercapai secara maksimal. Dengan keaktifan siswa dalam proses belajar mengajar, siswa mempunyai pengalaman belajar yang menyenangkan dan berkesan dalam pembelajaran IPS.

Ada berbagai model pembelajaran yang potensial untuk kompetensi siswa diantaranya Pair Check, Jigsaw, Student Team Achievement Division (STAD), Role Playing, dan Numbered-Heads Together (NHT), Group Investigation, Example Nonexample, Picture and Picture, Think Pair Share, Make a Macth. Menurut peneliti setelah membandingkan berbagai model tersebut diatas, model Pair Check dan Numbered-Heads Together (NHT) lebih potensial untuk memecahkan permasalahan tersebut karena berdasarkan penelitian Utami, Sri (2014) Meningkatkan Hasil Belajar Bahasa Indonesia menggunakan Model Kooperatif Pair Check Siswa Kelas V SDN Ngawen 02 Kecamatan Margorejo Kabupaten Pati Semester I Tahun 2013 / 2014. Universitas Kristen Satya Wacana. Hasil penelitiannya menunjukkan bahwa pembelajaran menggunakan Model pembelajaran Kooperatif Pair Check pada pelajaran Bahasa Indonesia dapat meningkatkan hasil belajar siswa.

Selain model pembelajaran Pair Check, model pembelajaran NumberedHeads Together (NHT) merupakan alternatif lain untuk memecahkan permasalahan pembelajaran IPS. Dalam penelitian Nopi. Pengaruh Penerapan Model Pembelajaran Kooperatif Tipe NHT (Numbered-Heads Together) Terhadap Hasil Belajar IPS Siswa Kelas V SD Salatiga. Program Studi PGSD. Universitas Kristen Satya Wacana. Salatiga. Hasil penelitiannya menunjukkan didapat nilai $t$ senilai 7.232 dengan tingkat signifikan lebih kecil dari 0.005 yaitu 0.000 , dengan hasil tersebut menunjukkan bahwa hasil belajar IPS menggunakan model pembelajaran 
Numbered-Heads Together (NHT) lebih baik. Menurut Hosnan (2014: 252) pembelajaran kooperatif tipe Numbered-Heads Together (NHT) merupakan salah satu tipe pembelajaran kooperatif yang menekankan pada struktur khusus yang dirancang untuk mempengaruhi pola interaksi siswa dan memiliki tujuan untuk meningkatkan penguasaaan akademik. Pada dasarnya model pembelajaran Numbered-Heads Together (NHT) adalah pembelajaran yang menekankan kerjasama dalam diskusi kelompok atau pembelajaran kooperatif untuk meningkatkan keaktifan dan hasil belajar siswa.

Ditinjau dari uraian permasalahan di atas, bertolak dari akar penyebab masalah dan didasarkan kajian teori maka didapatkan alternatif pemecahan masalah yaitu dengan menggunakan model Pair Check dan Numbered-Heads Together (NHT).

Menurut Huda (2013: 211) model Pair Check menerapkan pembelajaran kooperatif yang menuntut kemandirian dan kemampuan siswa dalam menyelesaikan persoalan, metode ini juga melatih tanggung jawab sosial siswa, kerja sama dan kemampuan memberi penilaian. Ada beberapa kelebihan dari model pair check, antara lain: (1) meningkatkan kerja sama antar siswa, (2) peer tutoring, (3) meningkatkan pemahaman atas konsep dan/atau proses pembelajaran IPS

Menurut Ahmad Zuhdi (2010: 65) model pembelajaran Numbered-Heads Together (NHT) memiliki beberapa kelebihan, antara lain: (1) setiap siswa menjadi siap semua, (2) dapat melakukan diskusi dengan sungguh-sungguh pembelajaran IPS. Adapun permasalahan yang akan diteliti adalah: apakah ada perbedaan hasil belajar IPS yang signifikan dalam pembelajaran menggunakan model Pair Check dan model Numbered-Heads Together (NHT) pada siswa kelas IV SDN gugus Mahesa Jenar Ambarawa? Penelitian ini diharapkan dapat memberikan manfaat Bagi sekolah masukan lembaga pendidikan untuk mengembangkan strategi belajar mengajar yang tepat dalam usaha untuk meningkatkan mutu lulusan supaya dapat bersaing di tingkat nasional. Bagi guru memberikan masukan untuk menerapkan model pembelajaran Pair Check dan Numbered-Heads Together (NHT) dalam kegiatan belajar mengajar di kelas untuk meningkatkan keaktifan dan hasil belajar siswa. Sedangkan bagi siswa untuk mendorong siswa agar berperan aktif, bekerja sama dan berfikir kritis dalam kehidupan sehari-hari yang berkaitan dengan mata pelajaran IPS.

\section{KAJIAN PUSTAKA}

\section{Hakikat Pembelajaran IPS}

Menurut Susanto (2013: 137) IPS adalah ilmu pengetahuan yang mengkaji berbagai disiplin ilmu sosial dan humaniora serta kegiatan dasar manusia yang 
Keefektifan Model Pembelajaran Pair Check Dan Numbered-Heads Together (NHT) ditinjau dari Hasil Belajar Dalam Pembelajaran IPS Kelas 4 SDN Gugus Mahesa Jenar Ambarawa (Galuh Adi Prakoso)

dikemas secara ilmiah dalam rangka memberi wawasan dan pemahaman yang mendalam kepada peserta didik. IPS adalah bidang studi yang mempelajari, menelaah, menganalisis gejala dan masalah sosial di masyarakat dengan meninjau dari berbagai aspek kehidupan atau satu perpaduan (Sardjiyo, 2008: 126). IPS dirumuskan atas dasar realitas dan fenomena sosial yang mewujudkan satu pendekatan interdisipliner dari aspek dan cabang ilmu sosial (Trianto, 2012: 171).

IPS seperti halnya IPA, matematika, dan bahasa indonesia merupakan bidang studi. Ruang lingkup IPS adalah hal-hal yang berkenaan dengan manusia dan kehidupannya meliputi semua aspek kehidupan manusia sebagai anggota masyarakat. Aspek kehidupan masyarakat dikaji berdasarkan satu kesatuan gejala sosial atau masalah sosial. Pengajaran IPS (social studies), sangat penting bagi jenjang pendidikan dasar dan menengah karena siswa yang datang ke sekolah berasal dari lingkungan yang berbeda-beda. Pengenalan mereka tentang masyarakat tempat mereka menjadi diwarnai oleh lingkungan mereka tersebut. Sekolah bukanlah satu-satunya wahana atau sarana untuk mengenal masyarakat. Para siswa dapat belajar mengenal dan mempelajari masyarakat baik melalui media massa, media cetak maupun media elektronika, misalnya melalui acara televisi, siaran radio, membaca koran.

Menurut Sardjiyo (2008: 1.28-1.29) secara keseluruhan tujuan pendidikan IPS di SD adalah sebagai berikut:

1. Membekali peserta didik dengan pengetahuan sosial yang berguna dalam kehidupannya kelak di masyarakat.

2. Membekali peserta didik dengan kemampuan mengidentifikasi, menganalisis dan menyusun alternatif pemecahan masalah sosial yang terjadi dalam kehidupan di masyarakat.

3. Membekali peserta didik dengan kemampuan berkomunikasi dengan sesama warga masyarakat dan berbagai bidang keilmuan serta bidang keahlian.

4. Membekali peserta didik dengan kesadaran, sikap mental yang positif dan keterampilan terhadap pemanfaatan lingkungan hidup yang menjadi bagian dari kehidupan tersebut.

5. Membekali peserta didik dengan kemampuan mengembangkan pengetahuan dan keilmuan IPS sesuai dengan perkembangan kehidupan, masyarakat, ilmu pengetahuan dan teknologi.

Untuk mencapai tujuan pembelajaran IPS yang sudah dijabarkan diatas maka peran guru sebagai pendidik dan motivator sangat berperan penting dalam tercapainya tujuan pembelajaran IPS. Guru sebagai penentu keberhasilan proses pembelajaran maka tentunya harus dituntut kreatif dan inovatif dalam pelaksanaan pembelajaran baik menggunakan metode dan model pembelajaran yang tepat dan sesuai kebutuhan siswa. 
Ada berbagai model pembelajaran kooperatif, kreatif, dan inovatif antara lain adalah Think Pair Share (TPS), Jigsaw, Role Playing, Student Team Achievement Division (STAD), Discovery Learning, Make a Macth, Picture and Picture, Example Nonexample, Probelem Based Learning,Snow Balling,Group Investigation, Numbered-Heads Together (NHT), Pair Check dan lain-lain.

Menurut peneliti model yang potensial untuk pembelajaran IPS adalah model Pair Check dan Numbered-Heads Together (NHT) karena kedua model pembelajaran tersebut adalah model pembelajaran kooperatif dimana dalam pembelajaran kooperatif, siswa belajar bersama dalam kelompok-kelompok kecil yang saling membantu satu sama lain. Pada pembelajaran kooperatif diajarkan keterampilan-keterampilan khusus agar siswa dapat bekerja sama dengan baik dengan kelompoknya untuk mencapai ketuntasan. Maka dari itu kedua model Pair Check dan Numbered-Heads Together (NHT) diharapkan siswa dapat lebih memahami pembelajaran IPS Untuk lebih jelasnya berikut ini adalah penjelasan tentang model Pair Check dan Numbered-Heads Together (NHT).

\section{Model pembelajaran Pair Check}

Dalam Huda (2013: 211) Pair Check merupakan model pembelajaran berkelompok antar dua orang atau berpasangan yang dipopulerkan oleh Spencer Kagan pada 1990.Model ini menerapkan pembelajaran kooperatif yang menuntut kemandirian dan kemampuan siswa dalam menyelesaikan persoalan, model ini juga melatih tanggung jawab sosial siswa, kerja sama dan kemampuan memberi penilaian.

Menurut Huda (2013: 211), secara umum, sintak pembelajaran model pembelajaran pair check adalah (1) bekerja berpasangan; (2) pembagian peran partner dan pelatih; (3) pelatih memberi soal, partner menjawab; (4) pengecekan jawaban(5) bertukar peran; (6) penyimpulan; (7) evaluasi; dan (8) refleksi.

Menurut Huda (2013:212) model Pair Check memiliki kelebihankelebihan, antara lain : (1) Meningkatkan kerja sama antar siswa, (2) Peer tutoring, (3) Meningkatkan pemahaman atas konsep dan/atau proses pembelajaran (4) Melatih siswa berkomunikasi dengan baik dengan teman sebangku

\section{Model Pembelajaran Numbered-Heads Together (NHT)}

Menurut Hosnan (2014: 252) pembelajaran kooperatif tipe NumberedHeads Together (NHT) merupakan salah satu tipe pembelajaran kooperatif yang menekankan pada struktur khusus yang dirancang untuk mempengaruhi pola interaksi siswa dan memiliki tujuan untuk meningkatkan penguasaaan akademik. 
Keefektifan Model Pembelajaran Pair Check Dan Numbered-Heads Together (NHT) ditinjau dari Hasil Belajar Dalam Pembelajaran IPS Kelas 4 SDN Gugus Mahesa Jenar Ambarawa (Galuh Adi Prakoso)

Menurut Huda (2013: 213) sintak pembelajaran model pembelajaran Numbered-Heads Together (NHT) sebagai berikut: (1) siswa dibagi ke dalam kelompok-kelompok; (2) masing-masing siswa dalam kelompok diberi nomer; (3) guru memberi tugas/pertanyaan pada masing-masing kelompok untuk mengerjakannya; (4) setiap kelompok mulai berdiskusi untuk menemukan jawaban yang dianggap paling tepat dan memastikan semua anggota kelompok mengetahui jawaban tersebut; (5) guru memanggil salah satu nomer secara acak; (6) siswa dengan nomer yang dipanggil mempresentasikan jawaban dari hasil diskusi kelompok mereka.

Menurut Ahmad Zuhdi (2010: 65) kelebihan model NHT adalah (1) setiap siswa menjadi siap semua, (2) dapat melakukan diskusi dengan sungguh-sungguh, (3)siswa yang pandai dapat mengajari siswa yang kurang pandai.

\section{Keefektifan Pembelajaran}

Keefektifan pembelajaran menurut (Sadiman, 1987 dalam Trianto, 2010: 20) adalah hasil guna yang diperoleh setelah pelaksanaan proses belajar mengajar. Menurut tim pembina matakuliah Didaktik Metodik kurikulum IKIP Surabaya (1988) dalam Trianto (2010: 20) bahan efisiensi dan keefektifan mengajar dalam proses interaksi belajar belajar yang baik adalah segala daya dan upaya para guru untuk membantu para siswa agar bisa belajar dengan baik. Untuk mengetahui keefektifan mengajar, dengan memberikan tes. Sebab hasil tes dapat dipakai untuk mengevaluasi berbagai aspek proses pembelajaran.

Kegiatan pembelajaran yang efektif merupakan hasil dari manajemen kelas yang efektif pula. Hal ini diwujudkan oleh guru melalui beragam strategi yang dapat meningkatkan kebiasaan-kebiasaan baik dalam diri siswa misalnya disiplin, antusias, aktif, dan kreatif. Aktivitas-aktivitas pembelajaran di kelas mulai dari kegiatan awal sampai dengan akhir diharapkan mampu membantu siswa memahami materi pembelajaran yang disampaikan, misalnya menggunakan kegiatan apersepsi yang mendukung, menggunakan media yang cocok untuk materi pembelajaran tersebut,dan memberikan tugas-tugas mandiri.

\section{Hasil Belajar}

Menurut Suprijono (2012: 7) hasil belajar adalah pola-pola perbuatan nilainilai, pengertian-pengertian, sikap-sikap, apresiasi dan keterampilan. Hasil belajar juga merupakan prestasi yang dicapai oleh seseorang dalam bidang tertentu untuk memperolehnya menggunakan standar sebagai pengukuran keberhasilan seseorang.

Hasil belajar merupakan perubahan perilaku secara menyeluruh bukan hanya pada satu aspek saja tetapi terpadu secara utuh (Anitah, 2008: 219). Guru harus memperhatikan secara seksama agar perilaku tersebut dapat dicapai sepenuhnya oleh siswa. Perwujudan hasil belajar akan selalu berkaitan dengan 
kegiatan evaluasi pembelajaran sehingga diperlukan adanya teknik dan prosedur evaluasi belajar yang dapat menilai secara efektif proses dan hasil belajar.

Menurut Susanto (2013: 5) hasil belajar yaitu perubahan yang terjadi pada diri siswa baik yang menyangkut aspek kognitif, afektif, dan psikomotor sebagai hasil dari kegiatan belajar. Menurut Nawawi (dalam Susanto, 2013: 5) hasil belajar dapat diartikan sebagai tingkat keberhasilan siswa dalam mempelajari materi pelajaran di sekolah yang dinyatakan skor yang diperoleh dari hasil tes mengenal sejumlah materi pelajaran tertentu.

Berdasarkan permasalahan dan kajian teoritik seperti telah diuraikan di atas, maka disusun kerangka pikir eksperimen yaitu sebagai berikut. IPS sebagai suatu program pendidikan yang merupakan suatu keseluruhan yang pada pokoknya mempersoalkan manusia dalam lingkungan alam fisik, maupun dalam lingkungan sosialnya. Mata pelajaran IPS disusun secara sistematis, komprehensif, dan terpadu dalam proses pembelajaran menuju kedewasaan dan keberhasilan dalam kehidupan di masyarakat. Proses pembelajaran IPS di kelas IV SDN Gugus Mahesa Jenar belum optimal, ini dikarenakan guru belum menggunakan model pembelajaran yang menarik, siswa kurang aktif dalam proses pembelajaran, siswa kurang tertarik dalam proses pembelajaran, pembelajaran masih berpusat pada guru, hasil belajar siswa rendah. Berdasarkan permasalah tersebut maka perlu dilakukan pembaharuan dalam pembelajaran. Pembelajaran dengan menggunakan model Pair Check dan Numbered-Heads Together (NHT) merupakan salah satu alternatif yang dapat dilakukan seorang guru dalam memberikan materi IPS.

Model Pair Check dan Numbered-Heads Together (NHT) diharapkan siswa dapat lebih berfikir kritis, aktif dan bekerja sama untuk memudahkan siswa mengerti apa yang sedang dipelajari di dalam proses pembelajaran dan dapat diaplikasikan dalam kehidupan sehari-hari agar menjadi siswa yang pandai dan berakhlak mulia.

Berdasarkan kajian pustaka dan kerangka pikir di atas, maka hipotesis penelitian ini adalah sebagai berikut.

$\mathrm{H}_{0}$ : Tidak terdapat perbedaan hasil belajar yang signifikan antara pembelajaran IPS yang dilaksanakan menggunakan model Pair Check dengan model Numbered-Head Together (NHT) pada siswa kelas IV SDN Gugus Mahesa Jenar Ambarawa.

$\mathrm{H}_{\mathrm{a}}$ : Terdapat perbedaaan hasil belajar yang signifikan antara pembelajaran IPS yang dilaksanakan menggunakan model Pair Check dengan model Numbered-Head Together (NHT) pada siswa kelas IV SDN Gugus Mahesa Jenar Ambarawa. 
Keefektifan Model Pembelajaran Pair Check Dan Numbered-Heads Together (NHT) ditinjau dari Hasil Belajar Dalam Pembelajaran IPS Kelas 4 SDN Gugus Mahesa Jenar Ambarawa (Galuh Adi Prakoso)

\section{METODE PENELITIAN}

Jenis penelitian yang digunakan dalam penelitian ini adalah penelitian eksperimen jenis quasi eksperiment design. Desain penelitian yang akan digunakan adalah Nonequivalent Control Group Design. Digunakannya desain penelitian ini karena hanya pada desain ini kelompok eksperimen maupun kelompok kontrol tidak dipilih secara random (Sugiyono, 2012: 79). Penelitian ini dilaksanakan di SD inti yaitu SDN Sudirman dan SD imbas yaitu SDN Lodoyong 02 dan SDN Tambakboyo 01, Gugus Mahesa Jenar, Kecamatan Ambarawa, Kabupaten Semarang, pada kelas IV semester II tahun pelajaran 2014/2015. Waktu penelitian dilaksanakan pada bulan Maret 2015 sampai Juni 2015 dan dilakukan secara bertahap.

Populasi pada penelitian ini adalah SDN Gugus Mahesa Jenar Ambarawa Sampel dari penelitian ini adalah siswa kelas IVA SDN Sudirman dan kelas IV SDN Lodoyong 02 sebagai kelas eksperimen serta kelas IV B SDN Sudirman dan kelas IV SDN Tambakboyo 01 sebagai kelas kontrol. Pada penelitian ini menggunakan teknik sampling Cluster Sampling (Area Sampling) karena penelitian pada gugus sekolah dasar. Teknik sampling daerah digunakan untuk menentukan sampel bila objek yang diteliti atau sumber sangat luas (Sugiyono, 2012: 83). Variabel dalam penelitian ini yaitu terdapat variabel X dan variabel Y. Variabel X dalam penelitian ini adalah model pembelajaran Pair Check dan model pembelajaran Numbered-Heads Together (NHT). Teknik pengumpulan data dengan tes dan observasi. Sedangkan instrumen pengumpulan data yang digunakan adalah tes tertulis, observasi, dan wawancara.

Uji coba instrumen dalam penelitian ini adalah menggunakan uji validitas soal dan uji reliabilitas soal tes. Sebelum penelitian ini dilakukan ada beberapa syarat yang harus dilakukan yaitu melakukan uji homogenitas untuk mengetahui apakah kelas yang digunakan untuk penelitian tersebut homogen dan uji normalitas varian data. Setelah dilakukan uji homogenitas dan mormalitas dilakukan uji hipotes untuk menguji signifikasi perbedaan mean antara kelompok eksperimen dan kelompok kontrol analisis data yang digunakan adalah uji t-test. Uji t-test digunakan untuk menguji signifikasi perbedaan mean antara kelas eksperimen dan kelas kontrol. Uji t-test yang digunakan adalah uji dua sampel tidak berhubungan (Independent Samples T Test.). Hipotesis statistik dapat dirumuskan sebagai berikut:

1. $\mathrm{H}_{0}$ : Jika nilai $\mu$ model pembelajaran Pair Check = model NumberedHeads Together (NHT), maka H0 diterima dan $\mathrm{H} 1$ ditolak.

Artinya tidak ada pengaruh yang signifikan model pembelajaran Pair Check dan Numbered-Heads Together (NHT) terhadap hasil belajar IPS.

2. $\mathrm{H}_{\mathrm{a}}$ : Jika nilai $\mu$ model pembelajaran Pair Check $\neq$ model Numbered-Heads Together (NHT), maka H1 diterima dan H0 ditolak. 
Artinya ada pengaruh yang signifikan model pembelajaran Pair Check dan Numbered-Heads Together (NHT).terhadap hasil belajar IPS.

\section{HASIL PENELITIAN DAN PEMBAHASAN}

\section{Hasil Penelitian pada Implementasi Pembelajaran dengan Model Pair Check sebagai Kelompok Eksperimen}

Dalam hasil penelitian ini dipaparkan mengenai proses pembelajaran dan tingkat hasil belajar IPS yang dicapai dengan menggunakan perlakuan model Pair Check pada kelompok eksperimen di SDN Sudirman Kelas IVA (SD Negeri Inti) dan SDN Lodoyong 02 (SD Imbas).

\section{Proses Pembelajaran IPS di Kelas IV SDN Sudirman Kelas IVA (SD Inti)}

Topik yang digunakan dalam penelitian ini adalah materi perkembangan teknologi produksi, komunikasi,dan transportasi yang didasarkan pada Standar Kompetensi 2. Mengenal sumber daya alam, kegiatan ekonomi, dan kemajuan teknologi di lingkungan kabupaten/kota dan provinsi, dan Kompetensi Dasar 2.3 Mengenal perkembangan teknologi produksi, komunikasi, dan transportasi serta pengalaman menggunakannya. Sedangkan indikator pencapaian kompetensinya adalah menyebutkan alat produksi, komunikasi dan transportasi masa lalu dan masa kini serta mengidentifikasi cara penggunaan dan perbedaan alat produksi, komunikasi dan transportasi pada masa lalu dan masa kini.

Berdasarkan hasil observasi guru dalam melaksanakan pembelajaran yang sesuai sintak telah mencapai $84,61 \%$, sedangkan yang belum dilaksanakan sintaknya adalah mencapai 15,39\%. Sebenarnya guru telah melaksanakan pembelajaran sesuai sintak model pembelajaran Pair Check tetapi ada langkahlangkah lain yang belum dilaksanakan guru, maka hasil observasi belum mencapai $100 \%$.

Data yang diambil yaitu nilai rata-rata kelas eksperimen (nilai pretest) sebelum proses pembelajaran dengan perlakuan model Pair Check sebesar 74,67 dengan standar deviasi 13,47439. Sedangkan setelah diberikan proses pembelajaran dengan perlakuan model Pair Check didapatkan nilai rata-rata (nilai posttest) meningkat menjadi 80,00 dengan standar deviasi 10,00. Hal lain yang tampak adalah nilai tertinggi yang dicapai pada pretest adalah 95 dan nilai terendahnya adalah 30. Sedangkan pada posttest nilai tertinggi yang berhasil dicapai adalah 100 dan nilai terendahnya adalah 60. Jumlah siswa yang mengikuti pretest dan posttest ini sebanyak 31 siswa. 
Keefektifan Model Pembelajaran Pair Check Dan Numbered-Heads Together (NHT) ditinjau dari Hasil Belajar Dalam Pembelajaran IPS Kelas 4 SDN Gugus Mahesa Jenar Ambarawa (Galuh Adi Prakoso)

\section{Proses Pembelajaran IPS di Kelas IV SDN Lodoyong 02 (SD Imbas)}

Topik yang digunakan dalam penelitian ini adalah materi mengenai jenisjenis tanah yang didasarkan pada Standar Kompetensi 2. Mengenal sumber daya alam, kegiatan ekonomi, dan kemajuan teknologi di lingkungan kabupaten/kota dan provinsi, dan Kompetensi Dasar 2.3 Mengenal perkembangan teknologi produksi, komunikasi, dan transportasi serta pengalaman menggunakannya. Sedangkan indikator pencapaian kompetensinya adalah menyebutkan alat produksi, komunikasi dan transportasi masa lalu dan masa kini serta mengidentifikasi cara penggunaan dan perbedaan alat produksi, komunikasi dan transportasi pada masa lalu dan masa kini.

Berdasarkan hasil observasi guru dalam melaksanakan pembelajaran yang sesuai sintak telah mencapai $80,76 \%$, sedangkan yang belum dilaksanakan sintaknya adalah mencapai $19,24 \%$. Sebenarnya guru telah melaksanakan pembelajaran sesuai sintak model pembelajaran Pair Check tetapi ada langkahlangkah lain yang belum dilaksanakan guru, maka hasil observasi belum mencapai $100 \%$.

Data yang diambil yaitu bahwa nilai rata-rata kelas eksperimen (nilai pretest) sebelum proses pembelajaran dengan perlakuan model Pair Check sebesar 56,71 dengan standar deviasi 15,99370. Sedangkan setelah diberikan proses pembelajaran dengan perlakuan model Pair Check didapatkan nilai rata-rata (nilai posttest) meningkat menjadi 62,57 dengan standar deviasi 12,06242 . Hal lain yang tampak adalah nilai tertinggi yang dicapai pada pretest adalah 85 dan nilai terendahnya adalah 30 . Sedangkan pada posttest nilai tertinggi yang berhasil dicapai adalah 90 dan nilai terendahnya adalah 35 . Jumlah siswa yang mengikuti pretest adalah 35 siswa sedangkan posttest sebanyak 33 siswa.

\section{Hasil Penelitian pada Implementasi Pembelajaran dengan Model Numbered- Heads Toghether (NHT) sebagai Kelompok Kontrol}

Dalam hasil penelitian ini dipaparkan mengenai proses pembelajaran dan tingkat hasil belajar IPS yang dicapai menggunakan perlakuan model pembelajaran Numbered-Heads Together (NHT) pada kelompok kontrol di SDN Sudirman Kelas IVB (SD Inti) dan SD Tambakboyo 01 (SD Imbas).

\section{Proses Pembelajaran IPS di Kelas IVB SDN Sudirman Kelas IVB (SD Inti)}

Topik yang digunakan dalam penelitian ini adalah materi mengenai jenisjenis tanah yang didasarkan pada Standar Kompetensi 2. Mengenal sumber daya alam, kegiatan ekonomi, dan kemajuan teknologi di lingkungan kabupaten/kota dan provinsi, dan Kompetensi Dasar 2.3 Mengenal perkembangan teknologi produksi, komunikasi, dan transportasi serta pengalaman menggunakannya Sedangkan indikator pencapaian kompetensinya adalah menyebutkan alat produksi, komunikasi 
dan transportasi masa lalu dan masa kini serta mengidentifikasi cara penggunaan dan perbedaan alat produksi, komunikasi dan transportasi pada masa lalu dan masa kini.

Berdasarkan hasil observasi guru dalam melaksanakan pembelajaran yang sesuai sintak telah mencapai 92,31\%, sedangkan yang belum dilaksanakan sintaknya adalah mencapai 7,69\%. Sebenarnya guru telah melaksanakan pembelajaran sesuai sintak model pembelajaran Numbered-Heads Together (NHT) tetapi ada langkah-langkah lain yang belum dilaksanakan guru, maka hasil observasi belum mencapai $100 \%$.

Dari data yang diambil yaitu nilai rata-rata kelas kontrol (nilai pretest) sebelum proses pembelajaran dengan perlakuan model Numbered-Heads Together (NHT) sebesar 78.38 dengan standar deviasi 10,27838. Sedangkan setelah diberikan proses pembelajaran dengan perlakuan model Numbered-Heads Together (NHT) didapatkan nilai rata-rata (nilai posttest) meningkat menjadi 82,83 dengan standar deviasi 10,47849 . Hal lain yang tampak adalah nilai tertinggi yang dicapai pada pretest adalah 95 dan nilai terendahnya adalah 40. Sedangkan pada posttest nilai tertinggi yang berhasil dicapai adalah 100 dan nilai terendahnya adalah 60. Jumlah siswa yang mengikuti pretest sebanyak 31 siswa dan posttest sebanyak 30 siswa.

\section{Proses Pembelajaran IPS di Kelas IV SDN Tambakboyo 01 (SD Imbas).}

Topik yang digunakan dalam penelitian ini adalah materi mengenai jenisjenis tanah yang didasarkan pada Standar Kompetensi 2. Mengenal sumber daya alam, kegiatan ekonomi, dan kemajuan teknologi di lingkungan kabupaten/kota dan provinsi, dan Kompetensi Dasar 2.3 Mengenal perkembangan teknologi produksi, komunikasi, dan transportasi serta pengalaman menggunakannya Sedangkan indikator pencapaian kompetensinya adalah menyebutkan alat produksi, komunikasi dan transportasi masa lalu dan masa kini serta mengidentifikasi cara penggunaan dan perbedaan alat produksi, komunikasi dan transportasi pada masa lalu dan masa kini.

Berdasarkan hasil observasi guru dalam melaksanakan pembelajaran yang sesuai sintak telah mencapai $88,46 \%$, sedangkan yang belum dilaksanakan sintaknya adalah mencapai $11,54 \%$. Sebenarnya guru telah melaksanakan pembelajaran sesuai sintak model pembelajaran Numbered-Heads Together (NHT) tetapi ada langkah-langkah lain yang belum dilaksanakan guru, maka hasil observasi belum mencapai $100 \%$.

Sesuai data yang telah diambil bahwa nilai rata-rata kelas kontrol (nilai pretest) sebelum proses pembelajaran dengan perlakuan model Numbered-Heads Toghether (NHT) sebesar 69,88 dengan standar deviasi 13,94624. Sedangkan 
Keefektifan Model Pembelajaran Pair Check Dan Numbered-Heads Together (NHT) ditinjau dari Hasil Belajar Dalam Pembelajaran IPS Kelas 4 SDN Gugus Mahesa Jenar Ambarawa (Galuh Adi Prakoso)

setelah diberikan proses pembelajaran dengan perlakuan model Numbered-Heads Toghether (NHT) didapatkan nilai rata-rata (nilai posttest) meningkat menjadi 75,95 dengan standar deviasi 14,74325 . Hal lain yang tampak adalah nilai tertinggi yang dicapai pada pretest dan posttest adalah 95 dan nilai terendahnya adalah 30 . Jumlah siswa yang mengikuti pretest dan posttest adalah 42 siswa.

\section{Deskripsi Komparasi Hasil Pengukuran}

Deskripsi komparasi ini memaparkan perbandingan hasil pengukuran dari kelompok eksperimen dan kelompok kontrol masing-masing SD Negeri (SD inti dan SD imbas) berdasarkan nilai pretest dan posttest. Deskripsi tersebut disajikan dalam bentuk tabel dan grafik sebagai berikut.

Diketahui bahwa terdapat perbedaan nilai rata-rata tahap pengukuran awal yang ditunjukkan oleh adanya selisih skor antara kelompok eksperimen dan kelompok kontrol sebesar 3,71 dimana nilai rata-rata kelompok kontrol lebih unggul. Sedangkan pada tahap pengukuran akhir juga terdapat perbedaan nilai ratarata yang ditunjukkan adanya selisih skor antara kelompok eksperimen dan kelompok kontrol sebesar 2,83 dimana nilai rata-rata kelompok kontrol lebih unggul.

Apabila dilihat dari hasil pengukuran pada tahap awal dan akhir, maka dapat diketahui gain score yang diperoleh yaitu sebesar 5,33 untuk kelompok eksperimen dan 4,45 untuk kelompok kontrol, untuk lebih jelasnya bisa dilihat pada tabel 1 berikut ini

Tabel 1. Komparasi Hasil Pengukuran Kelompok Eksperimen dan Kelompok Kontrol SD Negeri Inti Gugus Mahesa Jenar

\begin{tabular}{|c|c|c|c|}
\hline \multirow{2}{*}{ Tahap pengukuran } & \multicolumn{2}{|c|}{$\begin{array}{c}\text { Rerata skor (mean) } \\
\text { kelompok }\end{array}$} & \multirow{2}{*}{$\begin{array}{c}\text { Keterangan } \\
\text { selisih skor }\end{array}$} \\
\cline { 2 - 3 } & Eksperimen & Kontrol & \\
\hline Awal & 74,67 & 78,38 & $\mathbf{3 , 7 1}$ \\
\hline Akhir & 80,00 & 82.83 & $\mathbf{2 . 8 3}$ \\
\hline Gain score & $\mathbf{5 , 3 3}$ & $\mathbf{4 , 4 5}$ & \\
\hline
\end{tabular}

Berdasarkan data yang diperoleh diketahui bahwa terdapat perbedaan nilai rata-rata tahap pengukuran awal yang ditunjukkan oleh adanya selisih skor antara kelompok eksperimen dan kelompok kontrol sebesar 13,16 dimana nilai rata-rata kelompok kontrol lebih unggul. Sedangkan pada tahap pengukuran akhir juga terdapat perbedaan nilai rata-rata yang ditunjukkan adanya selisih skor antara kelompok eksperimen dan kelompok kontrol sebesar 13,38 dimana nilai rata-rata kelompok kontrol lebih unggul. 
Apabila dilihat dari hasil pengukuran pada tahap awal dan akhir, maka dapat diketahui gain score yang diperoleh yaitu sebesar 5,85 untuk kelompok eksperimen dan 6,07 untuk kelompok kontrol. Untuk lebih jelasnya deskripsi komparasi hasil pengukuran tersebut dapat dilihat pada tabel 2 berikut.

Tabel 2. Komparasi Hasil Pengukuran Kelompok Eksperimen dan Kelompok Kontrol SD Negeri Imbas Gugus Mahesa Jenar

\begin{tabular}{|c|c|c|c|}
\hline \multirow{2}{*}{$\begin{array}{c}\text { Tahap } \\
\text { pengukuran }\end{array}$} & \multicolumn{2}{|c|}{ Rerata skor (mean) kelompok } & \multirow{2}{*}{$\begin{array}{l}\text { Keterangan } \\
\text { selisih skor }\end{array}$} \\
\hline & Eksperimen & Kontrol & \\
\hline Awal & 56,72 & 69,88 & 13,16 \\
\hline Akhir & 62,57 & 75,95 & \multirow[t]{2}{*}{13,38} \\
\hline Gain score & 5,85 & 6,07 & \\
\hline
\end{tabular}

\section{Hasil Uji Perbedaan Rerata Hasil Belajar Menggunakan Model Pair Check dengan Numbered-Heads Together (NHT)}

Dalam hasil uji beda penelitian ini dipaparkan mengenai teknik analisis data yang digunakan yaitu uji prasyarat dan uji hipotesis. Uji prasyarat terdiri atas uji normalitas dan homogenitas yang digunakan untuk mengetahui distribusi kenormalan data dan tingkat kesetaraan dari data yang akan diuji t (beda rata-rata). Pengujian normalitas dan homogenitas data dianalisis dengan menggunakan bantuan SPSS 16 for windows. Uji normalitas pada SDN inti bahwa nilai asymp. Sig. (2-tailed) hasil pretest-posttest kelompok kontrol adalah 0,284 dan 0,425. Sedangkan hasil pretest-posttest kelompok eksperimen adalah 0,592 dan 0,531. Karena nilai signifikansi/probabilitas data-data tersebut $>0,05$ maka dapat disimpulkan bahwa populasi data hasil pretest-posttest kelompok kontrol dan kelompok eksperimen SD Negeri Inti berdistribusi normal. Selanjutnya pada SDN Imbas deketahui bahwa nilai asymp. Sig. (2-tailed) hasil pretest-posttest kelompok kontrol adalah 0,192 dan 0,081. Sedangkan hasil pretest-posttest kelompok eksperimen adalah 0,501 dan 0,633. Karena nilai signifikansi/probabilitas data pretest-posttest kelompok eksperimen dan kelompok kontrol tersebut > 0,05 maka dapat disimpulkan bahwa populasi data hasil pretest-posttest kelompok eksperimen dan kelompok kontrol SD Negeri Imbas berdistribusi normal.

Hasil uji normalitas terpenuhi selanjutnya yaitu uji homogenitas untuk mengetahui apakah populasi varian data homogen dengan menggunakan Levene Test dengan ketentuan apabila nilai probabilitas/signifikansi $>0.05$ maka dapat 
Keefektifan Model Pembelajaran Pair Check Dan Numbered-Heads Together (NHT) ditinjau dari Hasil Belajar Dalam Pembelajaran IPS Kelas 4 SDN Gugus Mahesa Jenar Ambarawa (Galuh Adi Prakoso)

dikatakan bahwa populasi data memiliki varian yang sama atau dengan kata lain data homogen.

Uji homogen pada SDN Inti diperoleh diketahui bahwa hasil output test of homogeneity of variance nilai pretest menunjukkan angka signifikansi yang ada adalah untuk probabilitas based on mean $=0,159$, untuk based on median $=0,150$, probabilitas based on median ang with adjusted $d f=0,150$ dan probabilitas based on trimmed mean $=0,156$. Sehingga dapat dikatakan bahwa data nilai pretest kelompok kontrol dan eksperimen SD Negeri Inti memiliki varian yang sama atau homogen, karena nilai probabilitas populasi data >0,05. Hasil untuk nilai posttestnya menunjukkan bahwa angka signifikansi yang diperoleh adalah untuk probabilitas based on mean $=0,624$, untuk based on median $=0,707$, probabilitas based on median ang with adjusted $d f=0,707$ dan probabilitas based on trimmed mean $=0,616$. Karena nilai probabilitas populasi data $>0,05$ maka dapat dikatakan bahwa data nilai posttest kelompok kontrol dan eksperimen SD Negeri Inti memiliki varian yang sama atau homogen. Sehingga dapat disimpulkan bahwa populasi data nilai pretest-posttest kelompok kontrol dan kelompok eksperimen SD Negeri Inti memiliki varian yang sama atau homogen.

Uji homogen tahap selanjutnya yaitu pada SDN Imbas yaitu diketahui bahwa hasil output test of homogeneity of variance nilai pretest menunjukkan angka signifikansi yang ada adalah untuk probabilitas based on mean $=0,236$, untuk based on median $=0,270$, probabilitas based on median ang with adjusted $d f=0,270$ dan probabilitas based on trimmed mean $=0,220$. Sehingga dapat dikatakan bahwa data nilai pretest kelompok kontrol dan eksperimen SD Negeri Imbas memiliki varian yang sama atau homogen, karena nilai probabilitas populasi data >0,05. Hasil untuk nilai posttestnya menunjukkan bahwa angka signifikansi yang diperoleh adalah untuk probabilitas based on mean $=0,468$, untuk based on median $=0,901$, probabilitas based on median ang with adjusted $d f=0,901$ dan probabilitas based on trimmed mean $=0,636$. Karena nilai probabilitas populasi data $>0,05$ maka dapat dikatakan bahwa data nilai posttest kelompok kontrol dan eksperimen SD Negeri Imbas memiliki varian yang sama atau homogen. Sehingga dapat disimpulkan bahwa populasi data nilai pretest-posttest kelompok kontrol dan kelompok eksperimen SD Negeri Imbas memiliki varian yang sama atau homogen.

Berdasarkan hasil dari uji normalitas yang menunjukkan bahwa persebaran data posttest berdistribusi normal dan uji homogenitas yang menunjukkan bahwa data posttest homogen, maka dengan demikian uji prasyarat telah terpenuhi sehingga populasi data posttest tersebut dapat dikenakan untuk uji t (uji beda ratarata) sebagai acuan menguji hipotesis yaitu ada/tidak perbedaan rata-rata nilai posttest yang signifikan antara kelompok eksperimen dan kelompok kontrol. Di bawah ini disajikan hasil uji t (uji beda rata-rata) kelompok eksperimen dan kelompok kontrol. Berikut, pada tabel 3 disajikan uji t (uji beda rata-rata) kelompok 
eksperimen dan kelompok kontrol. Analisis uji beda t-test menggunakan equal variances assumed (asumsi varian sama). Dari tabel 4.15 di atas dapat dilihat bahwa nilai t-test adalah $-3,297$ dengan sig. (2-tailed) 0,001. Karena nilai probabilitas < 0,05 maka dapat dikatakan bahwa terdapat perbedaan yang signifikan pada hasil posttest kelompok kontrol dan kelompok eksperimen.

Tabel 3. Hasil Uji t Nilai Posttest Kelompok Kontrol dan Eksperimen

Independent Samples Test

\begin{tabular}{|c|c|c|c|c|c|c|c|c|c|}
\hline & $\begin{array}{c}\text { Lever } \\
\text { Test } \\
\text { Equali } \\
\text { Variar }\end{array}$ & $\begin{array}{l}\text { ne's } \\
\text { for } \\
\text { ty of } \\
\text { ices }\end{array}$ & \multicolumn{7}{|c|}{ t-test for Equality of Means } \\
\hline & \multirow[t]{2}{*}{$\mathrm{F}$} & \multirow[t]{2}{*}{ Sig. } & \multirow[t]{2}{*}{$\mathrm{t}$} & \multirow[t]{2}{*}{ df } & \multirow[t]{2}{*}{$\begin{array}{l}\text { Sig. (2- } \\
\text { tailed) }\end{array}$} & \multirow[t]{2}{*}{$\begin{array}{c}\text { Mean } \\
\text { Difference }\end{array}$} & \multirow[t]{2}{*}{$\begin{array}{l}\text { Std. Error } \\
\text { Difference }\end{array}$} & \multicolumn{2}{|c|}{$\begin{array}{l}\text { 95\% Confidence } \\
\text { Interval of the } \\
\text { Difference }\end{array}$} \\
\hline & & & & & & & & Lower & Upper \\
\hline $\begin{array}{l}\text { Nilai post } \\
\text { test } \\
\text { Equal } \\
\text { variances } \\
\text { assumed }\end{array}$ & 1.792 & .183 & -3.297 & 134 & .001 & -7.80382 & 2.36682 & -12.48498 & -3.12266 \\
\hline $\begin{array}{l}\text { Equal } \\
\text { variances not } \\
\text { assumed }\end{array}$ & & & -3.289 & 130.575 & .001 & -7.80382 & 2.37291 & -12.49815 & -3.10949 \\
\hline
\end{tabular}

\section{Hasil Uji Hipotesis}

Hasil uji t (uji beda rata-rata) terhadap nilai posttest kelompok kontrol dan kelompok eksperimen dapat dijadikan acuan untuk menguji hipotesis. Hipotesis yang telah dirumuskan adalah sebagai berikut.

3. $\mathrm{H}_{0}$ : Tidak ada perbedaan hasil belajar yang signifikan dalam penerapan model pembelajaran kooperatif tipe Pair Check dan Numbered-Heads Together ditinjau dari hasil belajar IPS siswa kelas IV SDN Gugus Mahesa Jenar.

4. $\mathrm{H}_{\mathrm{a}}$ : Ada perbedaan hasil belajar yang signifikan dalam penerapan model pembelajaran kooperatif tipe Pair Check dan Numbered-Heads Together ditinjau dari belajar IPS siswa kelas IV SDN Gugus Mahesa Jenar.

Berdasarkan uji $\mathrm{t}$ uji (beda rata-rata) yang telah dilakukan terhadap nilai post test kelompok kontrol dan eksperimen di SDN Gugus Mahesa Jenar, maka diperoleh hasil yaitu nilai t-test sebesar -3,389, dengan sig. (2-tailed) 0,001. Karena angka signifikansi/probabilitas menunjukkan nilainya $<0,05$ maka H1 diterima 
Keefektifan Model Pembelajaran Pair Check Dan Numbered-Heads Together (NHT) ditinjau dari Hasil Belajar Dalam Pembelajaran IPS Kelas 4 SDN Gugus Mahesa Jenar Ambarawa (Galuh Adi Prakoso)

yaitu ada perbedaan hasil belajar yang signifikan dalam penerapan model pembelajaran kooperatif tipe Pair Check dan Numbered-Heads Together ditinjau dari hasil belajar IPS siswa kelas IV SDN Gugus Mahesa Jenar Kecamatan Ambarawa.

\section{Pembahasan}

Hasil analisis persyaratan keempat kelompok dari SD Negeri Inti dan SD Negeri Imbas adalah homogen karena nilai signifikan pretest dari kedua kelompok SD Inti adalah menunjukkan angka $>0,05$. Sedangkan untuk nilai posttestnya menunjukkan bahwa angka signifikansi yang diperoleh $>0,05$ maka dapat dikatakan bahwa data nilai posttest kelompok kontrol dan eksperimen SD Negeri Inti memiliki varian yang sama atau homogen. Sehingga dapat disimpulkan bahwa populasi data nilai pretest-posttest kelompok kontrol dan kelompok eksperimen SD Negeri Inti memiliki varian yang sama atau homogen.

Hasil dari nilai signifikan pretest dari kedua kelompok SD Negeri Imbas adalah menunjukkan angka signifikansi $>0,05$. Untuk nilai posttestnya menunjukkan bahwa angka signifikansi > 0,05 maka dapat dikatakan bahwa data nilai posttest kelompok kontrol dan eksperimen SD Negeri Imbas memiliki varian yang sama atau homogen. Sehingga dapat disimpulkan bahwa populasi data nilai pretest-posttest kelompok kontrol dan kelompok eksperimen SD Negeri Imbas memiliki varian yang sama atau homogen.

Kedua kelompok varian (kelas eksperimen dan kelas kontrol) dari SD Negeri Inti dan SD Negeri Imbas homogen, sehingga kelompok tersebut dapat dilakukan untuk penelitian. Dapat dilihat uji normalitas menunjukkan angka $>0,05$ maka dapat disimpulkan bahwa data hasil pretest-posttest kelompok eksperimen dan kelompok kontrol SD Negeri Inti berdistribusi normal.

Hasil daripada nilai asymp. Sig. (2-tailed) hasil pretest-posttest kelompok eksperimen dari SD Negeri Imbas pada uji mormalitas menunjukkan angka > 0,05 maka dapat disimpulkan bahwa populasi data hasil pretest-posttest kelompok eksperimen dan kelompok kontrol SD Negeri Imbas berdistribusi normal.

Analisis deskriptif dari skor hasil belajar siswa setelah pembelajaran dari SD Negeri Inti diketahui bahwa nilai tertinggi yang diperoleh dari kelompok eksperimen yaitu 100 dan nilai terendahnya 30, dengan rata-rata skor hasil belajar 80,00 . Sedangkan nilai tertinggi yang diperoleh pada kelompok kontrol yaitu 100 dan nilai terendahnya adalah 40 dengan rata-rata skor hasil belajar 83,83. Adapun dari 32 siswa kelompok eksperimen terdapat 29 siswa yang tuntas KKM mata pelajaran IPS kelas IVA di SDN Sudirman dengan persentase 90,62\% dan 3 siswa tidak tuntas KKM dengan persentase 9,38\%. Sedangkan pada 31 siswa kelompok kontrol terdapat 28 siswa tuntas KKM mata pelajaran IPS kelas IVB SDN Sudirman dengan presentase 90,32\% dan 3 siswa tidak tuntas KKM dengan presentase 9,68\%. 
Analisis deskriptif dari skor hasil belajar siswa setelah pembelajaran dari SD Negeri Imbas diketahui bahwa nilai tertinggi yang diperoleh dari kelompok eksperimen yaitu 90 dan nilai terendahnya 35, dengan rata-rata skor hasil belajar 62,57. Sedangkan nilai tertinggi yang diperoleh pada kelompok kontrol yaitu 95 dan nilai terendahnya adalah 30 dengan rata-rata skor hasil belajar 75,95. Adapun dari 31 siswa kelompok eksperimen terdapat 16 siswa yang tuntas KKM mata pelajaran IPS kelas IV di SDN Lodoyong 02 dengan persentase 51,61\% dan 15 siswa tidak tuntas KKM dengan persentase 48,39\%. Sedangkan pada 42 siswa kelompok kontrol terdapat 33 siswa tuntas KKM mata pelajaran IPS kelas IV SDN Tambakboyo 01 dengan presentase $78,57 \%$ dan 9 siswa tidak tuntas KKM dengan presentase $21,43 \%$.

Hasil analisis berikutnya yaitu melakukan analisis uji-T hasil belajar siswa kelas IV SD Inti Gugus Mahesa Jenar pada kolom F test (Levenes Test) bernilai 1,792. Sedangkan hasil uji t pada tabel tersebut bahwa diperoleh nilai $t$ hitung adalah 0,343 dan t tabel 1,9778 dengan probabilitas signifikansi (2-tailed) yaitu 0,732. Jadi nilai signifikansi 0,001 adalah kurang dari 0,05 maka dapat dikatakan bahwa perlakuan yang diberikan pada kelas eksperimen dan kelas kontrol di SDN Gugus Mahesa Jenar Kecamatan Ambarawa yaitu dengan model pembelajaran Pair Check dan Numbered-Heads Together (NHT) terdapat pengaruh antara model pembelajaran Pair Check dan Numbered-Heads Together (NHT) terhadap hasil belajar siswa pada pembelajaran IPS kelas IV SD Gugus Mahesa Jenar Ambarawa.

\section{SIMPULAN DAN SARAN}

\section{Simpulan}

Berdasarkan hasil penelitian dan pembahasan dapat disimpulkan bahwa berdasarkan hasil post test siswa pada kelompok eksperimen dan kelompok kontrol setelah dilakukan uji t (uji beda rata-rata) menunjukkan signifikansi 0,001 karena signifikan kurang dari 0,05 maka ada perbedaan hasil belajar IPS yang signifikan dalam pembelajaran menggunakan model Pair Check dan model Numbered-Heads Together (NHT) pada siswa kelas IV SDN gugus Mahesa Jenar Ambarawa.

\section{Saran}

Berdasarkan pengalaman selama melakukan penelitian eksperimen pada siswa kelas IV SDN gugus Mahesa Jenar Ambarawa, peneliti dapat memberikan saran sebagai berikut. (1) Penelitian ini diharapkan dapat memberikan sumbangan positif dalam inovasi pembelajaran dalam dunia pendidikan, serta memperkaya penelitian yang sudah ada dengan pemanfaatan model Pair Check dan Numbered- 
Keefektifan Model Pembelajaran Pair Check Dan Numbered-Heads Together (NHT) ditinjau dari Hasil Belajar Dalam Pembelajaran IPS Kelas 4 SDN Gugus Mahesa Jenar Ambarawa (Galuh Adi Prakoso)

Heads Together (NHT). (2) Bagi sekolah untuk mengembangkan strategi belajar mengajar yang tepat dalam usaha untuk meningkatkan mutu lulusan supaya dapat bersaing di tingkat nasional. (3) Bagi guru untuk menerapkan model pembelajaran Numbered-Heads Together (NHT) dalam kegiatan belajar mengajar di kelas untuk meningkatkan keaktifan dan hasil belajar siswa. (4) Bagi siswa untuk mendorong siswa agar berperan aktif, bekerja sama dan berfikir kritis dalam kehidupan seharihari yang berkaitan dengan mata pelajaran IPS. (5) Bagi kepala sekolah untuk meningkatkan mutu pendidikan disekolahnya guna untuk mewujudkan pendidikan yang berlandaskan pancasila. (6) Untuk penelitian selanjutnya dengan menggunakan model lain pada anak lambat belajar dan perlu di identifikasi teorinya lebih lebih lanjut.

\section{DAFTAR PUSTAKA}

Anitah, Sri, dkk. 2008. Strategi Pembelajaran. Jakarta: Universitas Terbuka.

BSNP. 2006. Standar Isi untuk Pendidikan Dasar dan Menengah. Jakarta: Departemen Pendidikan Nasional, Direktorat Jendral Pendidikan Tinggi.

Hidayati, Mujine, Anwar. 2008. Pengembangan Pendidikan IPS SD. Jakarta: Direktorat Jendral Pendidikan Tinggi Departemen Pendidikan Nasional.

Hosnan. 2014. Pendekatan Saintifik dan Kontekstual dalam Pembelajaran Abad 21. Bogor: Ghalia Indonesia.

Huda, Miftahul. 2013. Model-Model Pengajaran dan Pembelajaran. Yogyakarta: Pustaka Pelajar.

Kemendikbud. 2013. Panduan Penilaian di SD. Jakarta: Kementerian Pendidikan dan Kebudayaan

Nopi. 2012. Pengaruh Penerapan Model Pembelajaran Kooperatif Tipe NHT (Numbered Heads Together) Terhadap Hasil Belajar IPS Siswa Kelas V SD Salatiga.Program studi PGSD Universitas Kristen Satya Wacana. Salatiga. http://repository.uksw.edu/. Diakses pada 5 April 2015., 09.35.

Sardjiyo, dkk. 2008. Pendidikan IPS di SD. Jakarta: Universitas Terbuka.

Solihatin, Etin dan Raharjo. 2011. Cooperative Learning: Analisis Model Pembelajaran IPS. Jakarta: Bumi Aksara.

Sugiyono. 2012. Metode Penelitian Kuantitatif Kualitatif dan R\&D. Bandung: Alfabeta.

Suprijono, Agus. 2012. Cooperative Learning Teori dan Aplikasi Paikem. Yogyakarta: Pustaka Pelajar.

Susanto, Ahmad. 2013. Teori Belajar dan Pembelajaran. Jakarta: Kencana Prenada Media Group.

Trianto. 2012. Model Pembelajaran Terpadu. Jakarta: Bumi Aksara. 
Scholaria, Vol. 5, No. 3, September 2015: 100 - 119

Undang-undang RI Nomor 20 Tahun 2003 tentang Sistem Pendidikan Nasional.

Utami, Sri. 2014. Meningkatkan Hasil Belajar Bahasa Indonesia menggunakan Model Kooperatif Pair Check Siswa Kelas V SDN Ngawen 02 Kecamatan Margorejo Kabupaten Pati Semester I Tahun 2013/2014.Universitas Kristen Satya Wacana. http://repository.uksw.edu/ Diakses pada 15 Maret 2015. 21.01.

Zuhdi, Ahmad. 2010. Guru Idola. Yogyakarta: Gen-k Publisher. 